\title{
On the links between globalization and poverty
}

\author{
Ann Harrison - Margaret McMillan
}

Received: 9 May 2006 / Accepted: 1 September $2006 /$

Published online: 19 December 2006

(C) Springer Science + Business Media B.V. 2006

\begin{abstract}
This article surveys the evidence on the linkages between globalization and poverty, drawing on a new NBER study that has been completed under the direction of one of the authors. We focus on two measures of globalization: trade and international capital flows. Past researchers have argued that global economic integration should help the poor since poor countries have a comparative advantage in producing goods that use unskilled labor. Our first conclusion is that such a simple interpretation of general equilibrium trade models is misleading. Second, the evidence suggests that the poor are more likely to share in the gains from globalization when there are complementary policies in place.Third, trade and foreign investment reforms have produced benefits for the poor in exporting sectors and sectors that receive foreign investment. Fourth, financial crises are very costly to the poor. Finally, the collected evidence suggests that globalization produces both winners and losers among the poor. The fact that some poor individuals are made worse off by trade or financial integration underscores the need for carefully targeted safety nets. We conclude the article by identifying a number of unanswered research questions regarding the impact of globalization on poverty.
\end{abstract}

Key words globalization · poverty · financial integration · trade reform · foreign investment.

\footnotetext{
A. Harrison $(\bowtie)$

University of California at Berkeley, 329 Giannini Hall, Berkeley, CA 94720, USA

e-mail: harrison@are.berkeley.edu

M. McMillan

Tufts University, Medford, MA, USA

e-mail: mmcmilla@tufts.edu
}

A. Harrison - M. McMillan

NBER, Cambridge, MA, USA 


\section{Introduction}

More than 1 billion people live in extreme poverty, which is defined by the World Bank as subsisting on less than $\$ 1$ a day. ${ }^{1}$ In 2001, fully half of the developing world lived on less than $\$ 2$ a day. Yet if we exclude sub-Saharan Africa and Eastern Europe, extreme poverty rates are lower today than they were 20 years ago. In the last two decades, the percentage of the world's population living in extreme poverty has fallen from 33 to $17 \%$. While poverty rates were falling, developing countries became increasingly integrated into the world trading system. If we use the share of exports in GDP as a measure of "globalization," then developing countries are now more "globalized" than high income countries. ${ }^{2}$

Does globalization reduce poverty? Will ongoing efforts to eliminate protection and increase world trade improve the lives of the world's poor? There is surprisingly little evidence on this question. Winters et al. [30], Goldberg and Pavcnik [14, 15], and Ravallion [27] survey the recent evidence. All three surveys acknowledge that they can only review the indirect evidence regarding the linkages between globalization and poverty. There have been almost no studies which test for the direct linkages between the two. ${ }^{3}$

Yet one of the biggest concerns of globalization's critics is its impact on the poor. This essay begins by summarizing some key findings from the forthcoming book Globalization and Poverty [17]. ${ }^{4}$ The 15 studies and accompanying discussions are part of a National Bureau of Economic Research (NBER) project that asks the following questions: How has global economic integration affected the poor in developing countries? Do trade reforms that cut import protection improve the lives of the poor? Has increasing financial integration led to more or less poverty? How have the poor fared during currency crises? Do agricultural support programs in rich countries hurt the poor in developing countries? Or do such programs in fact provide assistance by reducing the cost of food imports? Finally, does food aid hurt the poor by lowering the price of the goods they sell on local markets?

What do we mean by "globalization"? We focus on two aspects: (1) international trade in goods and (2) international movements of capital - including foreign investment, portfolio flows, and aid. The "orthodox" perspective on trade and poverty, based on the writings of David Dollar, Anne Krueger and others, is the following: openness to trade is good for growth, and growth is good for the poor. According to the orthodox view, it should follow

\footnotetext{
${ }^{1}$ All the poverty estimates in this paragraph are taken from the World Bank's official poverty website, at http:// iresearch.worldbank.org/PovcalNet/jsp/index.jsp. The \$1 a day poverty line is actually \$1.08 in 1993 purchasing power parity dollars.

${ }^{2}$ See "Trade Liberalization: Why So Much Controversy", by Ann Harrison and Helena Tang, in Growth in the 1990s: Learning from a decade of reform, edited by N. Roberto Zagha, World Bank, 2005.

${ }^{3}$ Winters et al. [30] write in their insightful and comprehensive survey that "there are no direct studies of the poverty effects of trade and trade liberalization." Goldberg and Pavcnik's [14, 15] excellent review points out that "while the literature on trade and inequality is voluminous, there is virtually no work to date on the relationship between trade liberalization and poverty." The few studies which do examine the links between globalization and poverty typically use computable general equilibrium models to disentangle the linkages between trade reform and poverty. While such research provides an important contribution to our understanding of the channels through which globalization could affect poverty, it is extremely important to be able to look at actual ex post evidence of the impact of trade and investment reforms on the poor. See the studies cited in Winters et al. [30], Ravallion [27], and Hertel and Winters [19]. Although there have been a number of recent studies on globalization and inequality, these volumes focus primarily on distributional consequences of globalization, rather than poverty. There are exceptions, of course. See, for example, Bhagwati's publications on this topic, including his (2000) ILO Nobel Peace Prize Lecture, published as "Social Justice in a Global Economy", as well as Bardhan [6] and Bardhan [7]. See also the forthcoming book by Hertel and Winters [19].

${ }^{4}$ The individual chapters may be downloaded from http:/www.nber.org/books/glob-pov/index.html.
} 
that openness to trade should reduce poverty. But what if openness to trade is associated with increasing inequality? If so, then average income may increase while those at the bottom of the income distribution become poorer. Anne Krueger and David Dollar argue that increased globalization will in fact reduce inequality in poor countries. This is because these countries have a comparative advantage in producing goods that use unskilled labor.

The most important lesson that emerges from the NBER volume is that orthodox perspectives on the linkages between globalization and poverty are misleading, if not downright wrong. Results from the 15 studies that make up the volume suggest that the gains from trade are highly unequal, and that the poor do not always benefit from globalization. This essay begins by summarizing six lessons that emerge from the forthcoming volume. The second part of the essay then turns to a number of unresolved issues and topics for further research.

\section{Six lessons on the linkages between globalization and poverty}

The chapters that make up the volume are creative and careful attempts to find answers to these questions. Though the topics and countries of analysis vary widely, they all seek to answer to provide insight into the impact of globalization on poverty. Thus, it is possible to draw some general lessons from these studies.

The poor in countries with an abundance of unskilled labor do not always gain from trade reform. One of the most famous theorems in international trade derived from the Heckscher-Ohlin (HO) model of international trade is the Stolper-Samuelson theorem. In its simplest form, this theorem suggests that the abundant factor should see an increase in its real income when a country opens up to trade. If the abundant factor in developing countries is unskilled labor, then this framework suggests that the poor (unskilled) in developing countries have the most to gain from trade. Anne Krueger [23] and Jagdish Bhagwati and T. N. Srinivasan [9] have all used this insight to argue that trade reforms in developing countries should be pro-poor, since these countries are most likely to have a comparative advantage in producing goods made with unskilled labor.

In their contribution to the NBER volume, Don Davis and Prachi Mishra [11] challenge the assumptions behind Stolper-Samuelson. Davis and Mishra argue that applying trade theory to suggest that liberalization will raise the wages of the unskilled in unskilledabundant countries is "worse than wrong - it is dangerous." They show that such arguments are based on a very narrow interpretation of the Stolper-Samuelson (SS) theorem. In particular, SS only holds if all countries produce all goods, if the goods imported from abroad and produced domestically are close substitutes, or if comparative advantage can be fixed vis-a-vis all trading partners.

In addition, the country studies on India [29] and Poland [13] show that labor is not nearly as mobile as the $\mathrm{HO}$ trade model assumes; for comparative advantage to increase the incomes of the unskilled, they need to be able to move out of contracting sectors and into expanding ones. Davis and Mishra, as well as the empirical case studies in the volume, suggest that the real world is not consistent with an HO world. The assumptions necessary for $\mathrm{HO}$ to work in reality are simply not present: there are too many barriers to entry and exit for firms, and too many barriers to labor mobility for workers.

Another reason why the poor may not gain from trade reforms is that developing countries have historically protected sectors that use unskilled labor, such as textiles and apparel. This pattern of protection, while at odds with simple interpretations of HO models, 
makes sense if standard assumptions (such as factor price equalization) are relaxed. Trade reforms may result in less protection for unskilled workers, who are most likely to be poor. Finally, penetrating global markets even in sectors that traditionally use unskilled labor requires more skills than the poor in developing countries typically possess.

The poor are more likely to share in the gains from globalization when there are complementary policies in place. The studies on India [29] and Colombia [14] suggest that globalization is more likely to benefit the poor if trade reforms are implemented in conjunction with reducing impediments to labor mobility. In Zambia [4], poor farmers are only expected to benefit from greater access to export markets if they also have access to credit, technical know-how, and other complementary inputs. The studies also point to the importance of social safety nets. In Mexico, if poor corn farmers had not received income support from the government, their real incomes would have been halved during the 1990s [3]. In Ethiopia, if food aid had not been well targeted, globalization would have had little impact on the poor [24]. The fact that other policies are needed to ensure that the benefits of trade are shared across the population suggests that relying on trade reforms alone to reduce poverty is likely to be disappointing.

Export growth and incoming foreign investment can reduce poverty. In the countries we study, poverty has fallen in regions where exports or foreign investment is growing. In Mexico, the poor in the most globalized regions have weathered macroeconomic crises better than their more isolated neighbors [16]. In India, opening up to foreign investment has been associated with a decline in poverty. The study on Zambia suggests that poor consumers gain from falling prices for the goods they buy, while poor producers in exporting sectors benefit from trade reform through higher prices for their goods. In Colombia, increasing export activity has been associated with an increase in compliance with labor legislation and a fall in poverty. In Poland, unskilled workers - who are the most likely to be poor - have gained from Poland's accession to the European Union.

Financial crises are costly to the poor. In Indonesia, poverty rates increased by at least $50 \%$ after the currency crisis in 1997 [28]. While recovery in Indonesia has been rapid, the Mexican economy has yet to recover fully from its 1995 peso crisis. Poverty rates in Mexico in the year 2000 were higher than they had been ten years earlier. Cross-country evidence also suggests that financial integration leads to higher consumption and output volatility in low-income countries [26]. One implication is that low income countries are more likely to benefit from financial integration if they also create reliable institutions and pursue macroeconomic stabilization policies (including the use of flexible exchange rate regimes). However, foreign investment flows have very different effects from other types of capital flows. While unrestricted capital flows are associated with a higher likelihood of poverty, foreign direct investment inflows are associated with a reduction in poverty. The poverty-reducing effects of FDI are clearly documented in the case studies on India and Mexico.

Globalization produces both winners and losers among the poor. The heterogeneity in outcomes associated with poverty-globalization linkages is one theme that emerges from a number of the different country case studies. Even within a single region, two sets of farmers producing the same good may be affected in opposite ways. In Mexico, while some small and most medium corn farmers saw their incomes fall by half in the 1990s, large corn farmers gained [3]. Across different countries, poor wage earners in exporting sectors or in 
sectors with incoming foreign investment gained from trade and investment reforms; conversely, poverty rates increased in previously protected sectors which were exposed to import competition. Within the same country or even the same region, a trade reform may lead to income losses for rural agricultural producers and income gains for rural or urban consumers of those same goods.

Different measures of globalization are associated with different poverty outcomes. How globalization is measured determines whether globalization is good for the poor. Measures of export activity and foreign investment are generally associated with poverty reduction, while removal of protection (an ex ante measure of globalization) or import shares (an ex post measure) are frequently associated with rising poverty. These different effects are consistent with short run models of international trade (such as the specific sector model) where factors of production cannot easily move from contracting or import-competing sectors to expanding or export oriented ones.

The case study on Colombia prepared by Penny Goldberg and Nina Pavcnik illustrates this heterogeneity of outcomes. Goldberg and Pavcnik investigate the impact of a large reduction in average tariffs in Colombia between 1984 and 1998 on a variety of urban labor market outcomes: the probability of becoming unemployed, minimum wage compliance, informal sector employment, and the incidence of poverty. The Colombian experience suggests that individuals in sectors with increasing import competition are likely to become poorer, while those in sectors where exports are growing are less likely to be poor. This is exactly the conclusion reached by Petia Topalova, who estimates the impact of trade reform in India on poverty. In the 1990s, India embarked on a remarkable trade reform, reversing decades of protectionist policies which had led to average tariffs in excess of ninety percent. Using household data which spans the period before and after the reform, Topalova relates changes in tariffs to changes in the incidence of poverty. Topalova finds that the rural poor gained less from the trade reforms than other income groups or the urban poor. Topalova also discusses why the rural poor gained less than other groups from liberalization: restrictions on labor mobility in rural areas have impeded adjustment. She finds that the negative impact of trade policy on poverty is reduced or eliminated in regions with flexible labor laws.

\section{Unresolved issues: A research agenda}

The series of papers in the NBER volume present the most comprehensive evidence to date on the linkages between globalization and poverty. However, this is a relatively new area of research for economists and many questions remain unanswered. In this section, we draw on the new evidence uncovered in the NBER project and suggest what we believe to be the most important areas for further research.

How do we integrate the poorest of the poor into the world trading system? One sixth of the world's population live in extreme poverty. Figuring out how to lift these people out of extreme poverty is arguably the most pressing issue. It is also the most difficult. The very poorest individuals tend to be untouched by globalization. This is evident among the poorest Mexican corn farmers who report that they never sell corn and among the poorest Ethiopian farmers who are net buyers of food. The number of extreme poor in sub-Saharan Africa has nearly doubled over the past two decades - going from around 170 to 310 million. Roughly half of sub-Saharan Africa lives in extreme poverty and this number has 
increased over the past two decades. Sub-Saharan Africa has seen very little in the way of foreign investment and still exports primarily unprocessed agricultural products.

More research is needed to identify the critical interventions required to lift these people out of poverty. What are the key constraints? How important is outside intervention? In light of the scarcity of resources available, creating a ranking of which complementary investment or reform is most needed to allow the poor to access world markets would be very useful.

What are the key issues in poverty measurement? As acceptable definitions of poverty shift over time, one question which needs to be addressed by poverty researchers is why they are focusing primarily on one aspect of the entire distribution of income. Presumably, focusing on the entire distribution of income - and hence income inequality - should become increasingly important. Once one focuses on the fact that poverty lines are constantly changing across countries and also within the same country over time, it becomes puzzling why poverty researchers do not also focus more on broader measures of income distribution as well.

In addition to explicitly focusing on the entire distribution of income, researchers also need to focus on issues related to measuring the absolute numbers of poor versus the incidence of poverty. As discussed by Emma Aisbett in her chapter for the NBER volume, the incidence of poverty has generally declined but the number of individuals who are living on less than $\$ 2$ a day has actually increased [1, 2]. Kanbur [20, 21] discusses this issue in more detail. Kanbur [21] also emphasizes the need to use other outcome measures, such as health and mortality, in assessing the lives of the poor. Those issues are also emphasized by Thomas and Frankenberg for the NBER volume.

Why hasn't increasing financial integration helped the poor more? One avenue through which globalization could affect the welfare of the poor is through financial liberalization, which has increased the scope for capital to flow to developing countries. In theory, openness to capital flows could alleviate poverty through several channels. If greater financial integration contributes to higher growth by expanding access to capital, expanding access to new technology, stimulating domestic financial sector development, reducing the cost of capital and alleviating domestic credit constraints, then such growth should reduce poverty. Access to international capital markets should also allow countries to smooth consumption shocks, reducing output or consumption volatility.

However, Eswar Prasad, Shang-Jin Wei, and Ayan Kose in their NBER contribution suggest that the impact of financial integration on poverty - via possible growth effects - is likely to be small [26]. They argue that since there are no clear linkages between financial integration and growth in the aggregate cross-country evidence, direct linkages between financial integration and poverty are also likely to be difficult to find. They also explore another link: whether financial integration has smoothed or exacerbated output and consumption volatility. Since the poor are likely to be hurt in periods of consumption volatility, income smoothing made possible by global financial integration could be beneficial to the poor. However, Prasad et al. find that the opposite is true: Financial globalization in developing countries is associated with higher consumption volatility.

Why hasn't international financial integration helped the poor more? Prasad et al. suggest that there is a threshold effect: beyond a certain level of financial integration (50\% of GDP), financial integration significantly reduces volatility. However, most developing countries are well below this threshold. Further research is necessary to understand why such a threshold might exist. What prevents lower income developing countries from exploiting the benefits of international financial integration? Is the answer that financial globalization must be approached with the right set of complementary policies, such as flexible exchange rates, 
macroeconomic stabilization policies, and the development of strong institutions? Prasad et al. suggest that if there is institutional development and good governance - including transparency in business and government transactions, control of corruption, rule of law, and financial supervisory capacity - then poor countries may also gain from financial integration. Yet more evidence is needed on this question.

How have the poor weathered the currency crises of the last two decades? Evidence from the Indonesian 1997 currency crisis shows that in the first year of the crisis, poverty rose by between 50 and $100 \%$, real wages declined by around $40 \%$ and household per capita consumption fell by around $15 \%$ [28]. Yet what is remarkable is that five years later, poverty in Indonesia is now below what it was at the start of the crisis. In contrast, between 1990 and 2000 poverty in Mexico increased. Although poverty increased less in Northern Mexico - the part of the country most exposed to the forces of globalization, nevertheless poverty in Mexico was higher in 2000 than in 1990.

These contrasting experiences suggest two questions for research. First, why was Indonesia able to recover so much quicker than Mexico? Were the special transfer programs in Indonesia - targeted at consumption and education of poor households - responsible for the different experiences in addressing poverty during this decade? Or, is it because Mexico entered into the North American Free Trade Agreement (NAFTA) just before the peso crisis? Second, are there long term consequences to the Indonesian financial crisis for the poor? Although recovery was rapid, households adjusted in the short run by cutting expenditures on durables, cutting health care visits, and cutting school attendance. Will there be long term consequences to this behavior, despite the fact that poverty rates quickly reverted back to pre-crisis levels?

Who among the poor are the winners from globalization? A number of the case studies point to winners among the poor from globalization. These include the poor wage earners in export-competing sectors and in sectors or regions that are recipients of foreign direct investment. Particularly in light of the vocal criticism leveled at globalization, these beneficiaries should be identified and emphasized in any future research agenda on the relationship between globalization and poverty. Of particular interest would be research that could further identify the impact of foreign investment inflows and export growth on poverty reduction in India and China.

Although research on China is constrained by the lack of micro datasets in the public domain, the relationship between rising inequality, falling poverty, and globalization deserves further investigation. While some researchers, notably [22] have found that increasing globalization is associated with higher inequality in China, others have found no relationship (Martin Ravallion), and for the NBER volume Shang-Jin Wei reports evidence suggesting that trade is associated with falling inequality. Differences in the approaches can be traced to different use of openness measures (Kanbur uses aggregate data on tariffs and trade shares, while Wei uses city-level data on exports) and different approaches.

While access to Chinese data is fairly restricted, the Indian Ministry of Statistics is quite open to researchers who wish to purchase data. Data are typically available before and after the 1991 Indian reforms, which would allow researchers to more carefully assess the effects of those reforms on the poor. The debate on the impact of the 1991 trade reforms in India on welfare outcomes is by no means resolved. While Topalova [29] suggests that the trade reforms hurt the poor in import-competing sectors in state with rigid labor laws, others dispute her findings. Even the evidence on the productivity effects of these reforms is not consistent across the different studies available. 
Can we better identify the complementarities between measures of globalization and other policies? It is increasingly evident that the poor are more likely to gain from openness to trade if there are other complementary policies in place. A number of recent studies emphasize the importance of complementary policies in determining the benefits or costs of trade reforms for developing countries [31]. For example, Bolaky and Freund [10] show that trade reforms actually lead to income losses in highly regulated economies.

However, much more work is needed to identify which types of policies should accompany trade reforms. There has been little analysis to show, for example, that financial globalization would be beneficial to developing countries if it was accompanied by flexible exchange rate regimes or better institutions. Additional work is needed to identify whether trade reforms introduced in conjunction with labor market reforms are more likely to reduce poverty, and how to properly design social safety nets to accompany trade reforms. While Mexico has been successful in targeting some of the poorest who were hurt by reforms, these programs are expensive and additional research could identify whether this approach is realistic for the very poorest countries.

Further research is needed to identify the source of the immobility of labor. While studies on India and Colombia show that some of these sources are artificial - stemming from labor market legislation which inhibits hiring and firing - Goh and Javorcik argue that much of the immobility of labor in Poland is due to societal factors which discourage workers from relocating. Further evidence, identifying the relationship between gross labor inflows and outflows and trade reforms would be useful in this regard.

The fact that the gains or losses from trade reforms to the poor may hinge on the mobility (or immobility) of labor needs to be more explicitly addressed in existing models of international trade. Some models adopt assumptions of perfect factor mobility (HO), while others assume no factor mobility (specific sector). Neither assumption is consistent with reality. In addition, many of globalization's critics perceive the world through the lens of imperfect competition. Yet most trade economists assume perfect competition or zero profits, which is not consistent with reality in at least some sectors of developing economies.

While the need for labor mobility is emphasized here, does this mean that protection to workers should be scrapped? Clearly the answer is no. Although workers need to be able to move from contracting to expanding sectors, dropping measures that provide rights for workers does not seem to be the answer either (see [18]). Workers in many developing countries still do not benefit from basic health and safety regulations, and the right to organize is frequently not recognized by governments. In many countries, workers seeking to form unions are fired or jailed, or even worse. Striking the right balance between safeguarding worker rights and ensuring labor mobility in order to create new jobs is difficult, but necessary.

Can we identify the dynamic effects of industrial country trade and aid policies on developing country agriculture? Several issues explored in the NBER volume include the role of industrial country policies in affecting the incidence of poverty in developing countries. Those studies suggest that at least in the short run, OECD subsidies and food aid have probably helped the poor in other countries. In their study of Ethiopian rural grain producers, Margaret McMillan and James Levinsohn explore the impact of food aid on both consumption and production of the rural poor. This paper addresses the concern that food aid further exacerbates poverty by depressing incomes of rural producers. While McMillan and Levinsohn confirm that a more optimal arrangement would be to buy food from local producers and distribute it to poor consumers, ${ }^{5}$ they also show that the net impact of food

\footnotetext{
${ }^{5}$ This assumes that local purchase does not drive prices up for some poor people. 


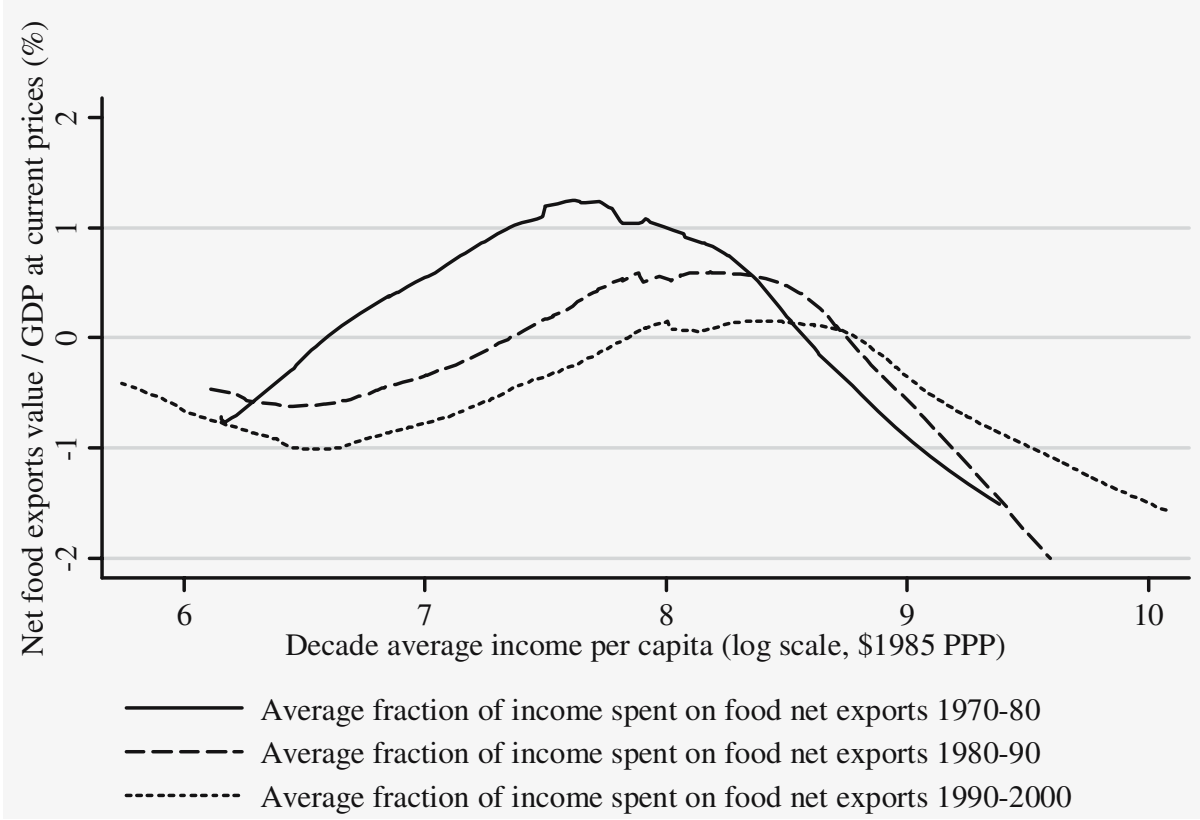

Fig. 1 Average income and net food exports by decade in a repeated cross section of developing countries.

aid on the poor in Ethiopia has been positive. This is because the poor in Ethiopia are primarily net consumers, rather than net producers of food, and consequently food aid has alleviated poverty.

However, further research is needed to identify whether there are longer term, dynamic effects. For example, even if the poor in Ethiopia are currently net beneficiaries from food aid, there exists the possibility that over the long run food aid has discouraged poor farmers from planting or investing, transforming them from net producers into net consumers.

Another issue which deserves further research is the impact of OECD agricultural subsidies on poverty. While the research presented in the NBER volume suggests that the poorest countries have been net beneficiaries of OECD agricultural subsidies because these poor countries are net food importers, decades of OECD subsidies may have discouraged poor countries from producing agricultural goods in the first place. Figure 1 shows that while a number of poor countries were net food importers even in the 1970s, there has been a shift over time leading these countries to become even more dependent on food imports. That shift may have been caused by OECD agricultural subsidies.

While there have been far-reaching reforms across developing countries in reducing barriers to trade, agriculture remains protected in many countries. Both China and India have protected agricultural sectors. In the coming decade, agriculture is likely to open up more to competition, in both developed and developing countries. Yet the highest incidence of poverty in developing countries is in the rural areas. What will be the impact of trade reforms targeted at the agricultural sector on the rural poor? How can complementary measures be introduced to cushion the negative impact? This remains an important area for future research. 


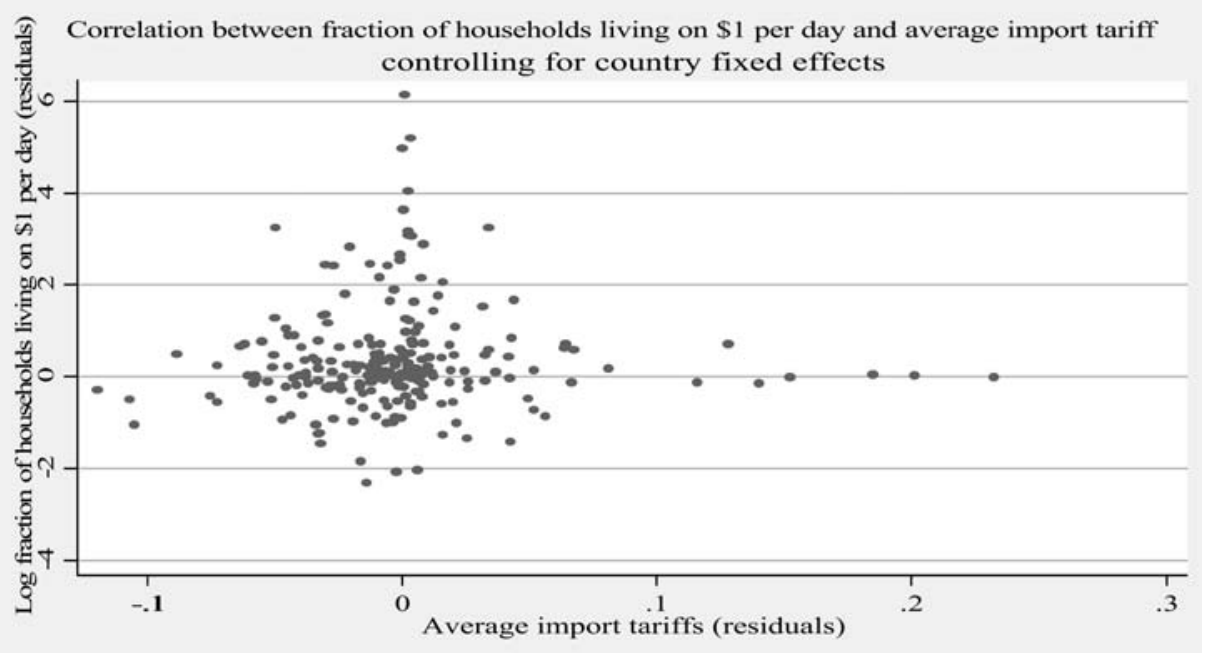

Fig. 2 Correlation between poverty and protection (tariffs). See [2].

Why is there no relationship between globalization and poverty in the aggregate crosscountry data? The evidence in Figure 2 suggests that there is no significant relationship between globalization (measured using average import tariffs) and poverty. Poverty is measured as the percentage of households in a country living on less than $\$ 1$ a day, measured in 1993 PPP dollars. There are several possible explanations for the lack of any robust association between globalization and poverty reduction in the aggregate data. One strong possibility, which is clearly revealed in the country case studies that make use of micro data using households or firms, is that there is too much heterogeneity in the effects of trade reforms on the poor. Since poor workers in import-competing sectors lose from reforms, while poor workers in export-oriented sectors gain (according to the studies by Goldberg and Pavcnik on Colombia and Topalova on India), it is not surprising that in the aggregate these different effects are lost.

Another possibility, which is related to the fact that there are so many heterogeneous effects of globalization on the poor, could be that cross-country data on poverty are too poor to yield meaningful results. Angus Deaton has argued that relying on national income data to impute poverty yields very different results from estimates based on household data. If we rely only on World Bank estimates of poverty, which are based on household surveys, the number of observations is very small. The World Bank poverty estimates provide only 2 or at most 3 data points over time for any one country. Consequently, it is not surprising that cross-country estimates using these data are so fragile.

A third possibility is that the aggregate relationship between globalization and poverty is not significant because the costs of trade reforms have fallen disproportionately on the poor. In light of our knowledge that openness to trade is generally associated with growth, and that sectors hit by import competition in regions like India and Colombia have gained less from trade reforms, the gains from trade in the aggregate have not been big enough to offset some of the adverse distributional consequences for the poor. The lack of any robust positive association between trade and poverty reduction could indicate that the growth gains from trade have failed to trickle down to the poor because they simply do not 
participate in the benefits. This interpretation of the results is consistent with the fact that a number of studies find that globalization is associated with increasing inequality. In the volume, for example, both Branko Milanovic (with Lynn Squire) and William Easterly find that increasing globalization is associated with increasing inequality [12, 25]. Consequently, a third possibility which is consistent with the evidence so far at the aggregate level is that the growth gains from trade have been wiped out by the adverse distributional outcomes for the poor. Identifying whether increasing inequality associated with globalization completely offsets any gains to the poor from the growth effects of trade should be an important priority.

\section{Conclusion}

In a recent lecture at a World Bank conference on poverty measurement, François Bourguignon pointed out that while we have made tremendous strides in understanding how to measure poverty, we still have a limited understanding of the impact of different economic policies on poverty outcomes. The forthcoming NBER book, Globalization and Poverty, seeks to address this gap by exploring the relationship between trade, foreign investment, and poverty outcomes. Nevertheless, many questions remain unanswered.

While significant progress has been made in identifying linkages between globalization and poverty outcomes, there is much that we do not know. In this essay, we discuss the lack of any correlation between globalization measures and poverty measures in the aggregate cross-country data, which is consistent with the possibility that aggregate growth gains from trade have bypassed the poor. We also discuss several other important issues for policy, including the need to identify key complementary policies that could cushion the adverse effects of globalization on the poor. Another important issue is the lack of labor mobility identified in many of the country studies. The fact that workers cannot easily relocate from contracting, import-competing sectors to expanding export sectors means that the short-run costs of reforms can be quite heavy. Identifying why workers cannot easily move in the wake of reforms remains a pressing issue for further research.

\section{References}

1. Aisbett, E.: Why are the critics so convinced that globalization is bad for the poor? In: Harrison A (ed.) Globalization and Poverty. University of Chicago Press for NBER (2006)

2. Aisbett, E., Harrison, A., Zwane, A.: Globalization and poverty: What is the Evidence? Prepared for a conference in honor of Jagdish Bhagwati's 70th birthday. University of Florida, Gainesville, FA (2005)

3. Ashraf, N., McMillan, M., Zwane, A.: My policies or yours: Have OECD agricultural policies affected incomes in developing countries? In: Harrison A. (ed.) Globalization and Poverty. University of Chicago Press for NBER (2006)

4. Balat, J., Porto, G.: Globalization and complementary policies. Poverty Impacts in Rural Zambia. In: Harrison A. (ed.) Globalization and Poverty, University of Chicago Press for NBER (2006)

5. Bardhan, P.: Social Justice in a Global Economy. ILO, available at http://www.ilo.org/public/english/ bureau/inst/papers/sopolecs/bardhan (2000)

6. Bardhan, P.: International economic integration and the poor. In: Siebert, H. (ed.) Global Governance: An Architecture for the World Economy. Springer, Berlin Heidelberg New York (2003)

7. Bardhan, P.: The impact of globalization on the poor. In: Collins, S., Graham, C. (eds.) Brookings Trade Forum. Brookings Institution, Washington, DC (2004)

8. Bhagwati, J.: In Defense of Globalization. Oxford University Press, USA (2004)

9. Bhagwati, J., Srinivasan, T.N.: Trade and poverty in the poor countries. AEA Papers and Proceedings 92 (2), 180-183 (2002)

10. Bolaky, B., Freund, C.L.: Trade, Regulations, and Growth. World Bank working paper (2004) 
11. Davis, D., Mishra, P.: Stolper-Samuelson is dead and other crimes of both theory and data. In: Harrison, A. (ed.) Globalization and Poverty. University of Chicago Press for NBER, Chicago, IL (2006)

12. Easterly, W.: Globalization, prosperity, and poverty. In: Harrison, A. (ed.) Globalization and Poverty. University of Chicago Press for NBER (2006)

13. Goh, C.-C., Javorcik, B. S.: Trade protection and industry wage structure in Poland. In: Harrison, A. (ed.) Globalization and Poverty. University of Chicago Press for National Bureau of Economic Research, Chicago, IL (2006)

14. Goldberg, P., Pavcnik, N.: Trade, inequality, and poverty: What do we know? Evidence from recent trade liberalization episodes in developing countries. NBER Working Paper No. 10593. In: Collins, S., Graham, C. (eds.) Brookings Trade Forum. Brookings Institution, Washington, DC (2004)

15. Goldberg, P., Pavcnik, N.: The effects of the Colombia trade liberalization on urban poverty. In: Harrison, A. (ed.) Globalization and Poverty. University of Chicago Press for National Bureau of Economic Research, Chicago, IL (2006)

16. Hanson, G.: Globalization, labor income, and poverty in Mexico. In: Harrison, A. (ed.) Globalization and Poverty. University of Chicago Press, Chicago, IL (2006)

17. Harrison, A. (ed.): Globalization and Poverty. University of Chicago Press for NBER, Chicago, IL (2006). Forthcoming

18. Harrison, A., Scorse, Jason.: Multinationals and anti-sweatshop activism. Working Paper, UC Berkeley (2006)

19. Hertel, T W., Winters, L A. (eds.): Poverty Impacts of a WTO Agreement: Putting Development back into the Doha Agenda. MacMillan, New York (2005)

20. Kanbur, R.: Economic policy, distribution, and poverty: The nature of disagreements. World Dev. 29(6), 1083-1094 (2001)

21. Kanbur, R.: Growth, Inequality, and Poverty: Some Hard Questions. Cornell University, Ithaca, NY (2004)

22. Kanbur, R., Zhang, X.: Fifty years of regional inequality in China: A journey through central planning, reform, and openness. Rev. Dev. Econ. 9(1), 87-106 (2005)

23. Krueger, A.: Trade and Employment in Developing Countries, 3: Synthesis and Conclusions. University of Chicago Press, Chicago, IL (1983)

24. Levinsohn, J., McMillan, M.: Does food aid harm the poor: Household evidence from Ethiopia. In: Harrison, A. (ed.) Globalization and Poverty. University of Chicago Press for NBER, Chicago, IL (2006)

25. Milanovic, B., Squire, L.: Does tariff liberalization increase inequality? Some empirical evidence. In: Harrison, A. (ed.) Globalization and Poverty. University of Chicago Press for NBER (2006)

26. Prasad, E S., Rogoff, K., Wei, S-J, Ayhan Kose, M.: Effects of financial globalization on developing countries: Some empirical evidence. In: Harrison, A. (ed.) Globalization and Poverty. University of Chicago Press for NBER, Chicago, IL (2006)

27. Ravallion, M.: Competing concepts of inequality in the globalization debate. In: Collins, S., Graham, C. (eds.) Brookings Trade Forum 2004. Brookings Institution, Washington, DC (2004)

28. Thomas, D., Frankenberg, E.: Financial crises and poverty: The case of Indonesia. In: Harrison, A. (ed.) Globalization and Poverty. University of Chicago Press for NBER (2006)

29. Topalova, P.: Trade liberalization, poverty and inequality: Evidence from Indian districts. Forthcoming In: Harrison, A. (ed.) Globalization and Poverty. University of Chicago Press for NBER, Chicago, IL (2006)

30. Winters, A L., McCulloch, N., McKay, A.: Trade liberalization and poverty: The evidence so far. J. Econ. Lit. XLII, 72-115 (March 2004)

31. World Bank:The growth experience: Lessons from the 1990s. In: Zagha, R. (ed.) World Bank, Washington, D.C. (2005) 
Copyright of Journal of Economic Inequality is the property of Springer Science \& Business Media B.V. and its content may not be copied or emailed to multiple sites or posted to a listserv without the copyright holder's express written permission. However, users may print, download, or email articles for individual use. 